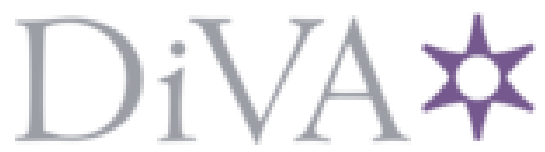

http://www.diva-portal.org

This is the published version of a paper presented at EuroCALL 2016.

Citation for the original published paper:

Allen, C., Hadjistassou, S K., Richardson, D. (2016)

Self-evaluation using iPads in EFL teaching practice.

In: Salomi Papadima-Sophocleous, Linda Bradley, Sylvie Thouësny (ed.), CALL communities and culture: short papers from EUROCALL 2016 (pp. 20-24).

https://doi.org/10.14705/rpnet.2016.eurocall2016.532

N.B. When citing this work, cite the original published paper.

Permanent link to this version:

http://urn.kb.se/resolve?urn=urn:nbn:se:Inu:diva-59165 


\title{
Self-evaluation using iPads in EFL teaching practice
}

\author{
Christopher Allen ${ }^{1}$, Stella K. Hadjistassou ${ }^{2}$, and David Richardson ${ }^{3}$
}

\begin{abstract}
The relentlessly accelerating global educational demands for teaching English as a Second or Foreign Language (ESL/EFL) in multiple, diverse, and often remote geographic locations constitute new challenges for academic institutions, teacher training and preparation programs, and teachers themselves. This study describes a novel approach where five elementary school preservice teachers teaching ESL/EFL borrowed an iPad mini from their teacher training institution customized with specific apps to record a series of five teaching sequences during their teaching practice placement in elementary schools in Tanzania and Kenya. All recorded sessions were uploaded to a Moodle Virtual Learning Environment (VLE) site specially constructed for the purpose of the teaching practice course. Results indicate that, apart from their experienced instructors' feedback on their teaching practice, the recorded sessions formed constructive tools for self-reflection, selfevaluation and the pursuit of possible paths for improvement.
\end{abstract}

Keywords: iPads, ESL, EFL, pre-service teachers, teaching practice, self-evaluation.

\section{Introduction}

Mobile devices, which fuse technology, culture, communication, learning and gaming, challenge some of the most salient social and cultural boundaries while at the same time inviting a discussion into their role in molding cultural expectations for teaching, learning, communication, and socialization. In ESL/EFL pedagogy and teacher preparation, scholarly research on mobile-based learning has delved into the pedagogical and learning implications of mobile devices (Goodwin-Jones, 2011; Hockly \& Dudeney, 2014; Kinash, Brand, \& Mathew, 2012; KukulskaHulme, 2009). Multiple studies have been undertaken and scholarly discussions have been built on the premise that, if mobile devices and software are exploited

\footnotetext{
1. Linnaeus University, Växjö, Sweden; christopher.allen@lnu.se

2. KIOS Research Center for Intelligent Systems and Networks, Nicosia, Cyprus; stella1@asu.edu

3. Linnaeus University, Växjö, Sweden; david.richardson@lnu.se
}

How to cite this article: Allen, C., Hadjistassou, S. K., \& Richardson, R. (2016). Self-evaluation using iPads in EFL teaching practice. In S. Papadima-Sophocleous, L. Bradley, \& S. Thouësny (Eds), CALL communities and culture - short papers from EUROCALL 2016 (pp. 20-24). Research-publishing.net. https://oi.org/10.14705/rpnet.2016.eurocall2016.532 
effectively in language learning contexts, they can expand the classroom ecology and galvanize students' learning (Vavoula, Pachler, \& Kukulska-Hulme, 2010; Kinash et al., 2012). Beyond the multi-purpose nature, mobility, adaptability, and interactivity of mobile devices, scholars have also looked into the impact that mobile devices can have on language learning (Kukulska-Hulme, 2009). KukulskaHulme (2009) makes a call to educators constructing mobile learning activities "to enrich these types of learning and enrich them with new possibilities" (p. 160). It is not only learning but also teaching in the form of teachers' self-evaluation with recordings of their classroom performance that could be enhanced through the use of mobile devices. Previous studies, such as Bolona Lopez, Ortiz, and Allen (2015) have demonstrated that smartphones could form effective tools for assessing EFL student teachers' teaching practices in Ecuador. However, limited attention has been paid to the use of iPads as tools to record and facilitate self-evaluation among pre-service teachers on teaching practice in geographically remote locations.

\section{Method}

This study aimed to investigate the role of iPads as tools to evaluate pre-service teachers' teaching practice and their perception on the integration of iPads in the selfconfrontation of the teachers with video recordings of their performance. In adopting a qualitative approach, this study offered preservice teachers a level of autonomy in selecting specific parts from their practical teaching experience and the opportunity to record sessions in specific pupil age range and cultural/institutional settings. It also gave 'a voice' to preservice teachers to share their experiences throughout this process (Levy, 2015). The study was conducted during the fall of 2015. Five female primary preservice teachers enrolled in a teaching practice course at a Swedish academic institution were provided with an iPad mini for their five-week practicum. The preservice course aimed to offer preservice teachers practical teaching opportunities to teach English to primary school children in diverse locations, such as Kenya and Tanzania. All preservice teachers had previously completed their practical teaching placement in Swedish schools. Prior to their departure, they attended an orientation session with two experienced teacher trainers, the first and third authors of this paper. Both instructors specialize in computer-assisted language learning, information communication and technology, and teacher training. During the orientation session, preservice teachers were introduced to the pedagogical expectations for the practice and received tech training on relevant applications and resources to facilitate communication with the instructors and video uploading on their iPads, such as Skype and Adobe Connect and Moodle. Figure 1 below provides a screenshot of the iPad minis provided to preservice teachers. 
Figure 1. Screenshot of the iPad minis prior to departure

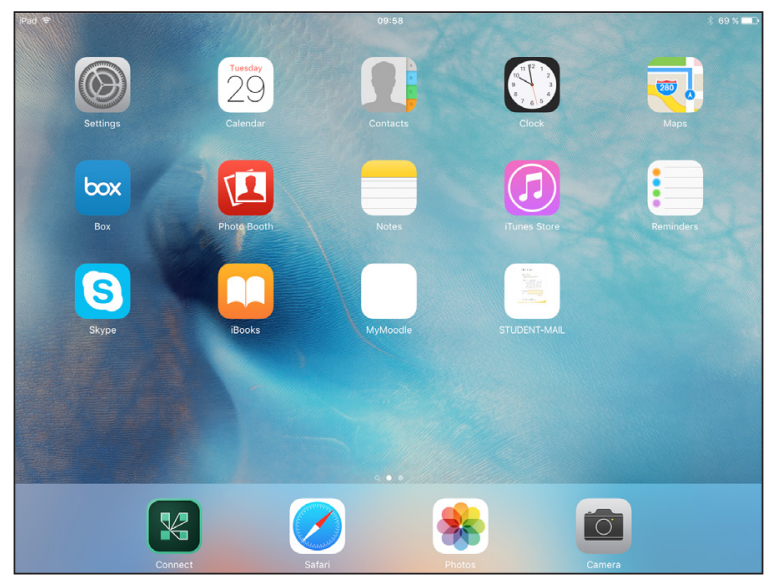

Students were invited to upload five shorter lesson sequence recordings on their academic institution's Moodle VLE site: (i) a brief video confirming their arrival in the host country and school site; (ii) the introduction of the subject of instruction and delivery of instructions to students; (iii) the delivery of a lesson on vocabulary, grammar, and/or pronunciation; (iv) the monitoring of group work and use of contingent feedback; and (v) the conclusion of the lesson and preparation for the next activities. These five recording sequences could be selected by the preservice teacher from any lesson during the practicum period; they did not have to be from the same lesson. The intention from the instructors' side was to provide feedback formatively following the upload of each lesson component throughout the practicum using the tools installed on the iPads. Following their return to Sweden, preservice teachers received summative feedback from their instructor and completed a written questionnaire which attempted to evaluate the learning experience through a mixture of open and fixed response questions.

\section{Results and discussion}

Each preservice teacher uploaded her five recordings on the Moodle VLE site and four of them responded to the written questionnaire. Upon their return to Sweden, they met with their instructors and received constructive feedback on their teaching techniques, student group work, delivery of lesson plans, classroom management, and other classroom issues that emerged during the recordings. Unfortunately, technological contractions and challenges, such as limited or complete lack of 
Wi-Fi access, inhibited the provision of feedback while students were teaching in the particular teaching context. All four preservice teachers addressed the lack of or limited Wi-Fi access in their questionnaires and considered it as a hindering mechanism in uploading their videos and receiving feedback. As Selma, a twentyfour year-old preservice teacher noted in her written response, "we couldn't upload our videos when we where [sic] away because of the internet connection".

Despite these technological challenges, all four preservice teachers perceived the use of iPads as effective tools for self-confrontation with recordings of their teaching performances. As they noted on their written questionnaires, viewing themselves in action while they were teaching and observing their teaching techniques, classroom dynamics, group work, and the delivery of their lesson plans played a central role in reflecting on their teaching practice and identifying possible ways to improve. In addition to their experienced instructors' feedback, preservice teachers critically reflected on their own teaching and pursued possible ways to improve. The use of these cultural artifacts or recordings enacted affordances for selfreflection and self-evaluation, while at the same time heightening awareness of the multiple classroom dynamics, management, and other pedagogical, instructional, and other learning constructs. For instance, as Felicia, another twenty-four yearold preservice teacher candidly admitted: "since you are able to see the recorded video after the lesson you see many things that you can improve, for example how you focus which pupils who gets your attention the most, or how you try to explain things". What they also particularly enjoyed was the flexibility and choice in selecting the recorded sessions that they felt more comfortable sharing with their instructors, which eliminated preservice teachers' level of anxiety. Selma summed it up best: "I think everybody should record themselves while teaching it feels wierd [sic] the first time you have to watch yourself but learned a lot from it! And now I am not nervous to have someone in the classroom when I teach and I am better at taking feedback".

\section{Conclusion}

The findings of this study demonstrate some of the possible implications that recorded sessions on iPads could have on preservice school teachers' initial endeavors as they break into the complex arena of teaching. Teaching constitutes a complex, demanding, and at the same time rewarding profession. However, preservice teachers need not only to receive constructive feedback from experienced teacher trainers but also to be presented with their own teaching performance as a means to reflect and evaluate their own teaching practice and identify possible 
ways to improve. The use of iPads to record their initial teaching experiences can contribute to this process by enacting affordances for preservice students to observe their teaching in action and critically evaluate their own teaching practice.

\section{Acknowledgements}

We would like to thank the Department of Language, Linnaeus University Sweden and the Kios Research Center for Intelligent Systems and Networks for financial support in attending the EUROCALL 2016 conference.

\section{References}

Bolona Lopez, M., Ortiz, M., \& Allen, C. (2015). Using mobile devices and the AdobeConnect web conferencing tool in the assessment of EFL student teacher performance. In F. Helm, L. Bradley, M. Guarda, \& S. Thouësny (Eds), Critical CALL - Proceedings of the 2015 EUROCALL Conference, Padova, Italy (pp. 77-83). Dublin Ireland: Research-publishing.net https://doi.org/10.14705/rpnet.2015.000313

Goodwin-Jones, R. (2011). Mobile apps for language learning. Language Learning \& Technology, 15(2), 2-11.

Hockly, N., \& Dudeney, G. (2014). Going mobile: teaching with hand-held devices. Delta Teacher Development.

Kinash, S., Brand, J., \& Mathew, T. (2012). Challenging mobile learning discourse throughresearch: student perceptions of Blackboard Mobile Learn and iPads. Australasian Journal of Educational Technology, 28(4), 639-655. https://oi.org/10.14742/ajet.832

Kukulska-Hulme, A. (2009). Will mobile learning change language learning? ReCALL, 21(2), 157-165. https://doi.org/10.1017/S0958344009000202

Levy, M. (2015). The role of qualitative approaches to research in CALL contexts: closing in on the learner's experience. CALICO Journal, 32(3), 554-568. https://doi.org/10.1558/ cj.v32i3.26620

Vavoula, G., Pachler, N., \& Kukulska-Hulme, A. (Eds). (2010). Researching mobile learning: frameworks, tools and research design (2nd ed.). Bern, Switzerland: Peter Lang AG, International Academic Publishers. 


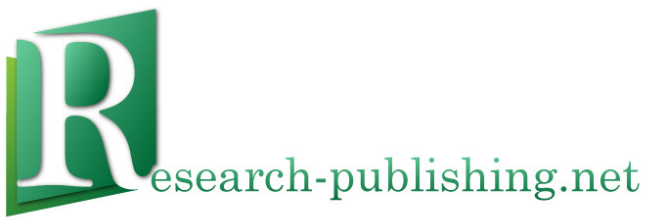

Published by Research-publishing.net, not-for-profit association Dublin, Ireland; Voillans, France, info@research-publishing.net

(C) 2016 by Editors (collective work)

(C) 2016 by Authors (individual work)

\section{CALL communities and culture - short papers from EUROCALL 2016 Edited by Salomi Papadima-Sophocleous, Linda Bradley, and Sylvie Thouësny}

Rights: All articles in this collection are published under the Attribution-NonCommercial -NoDerivatives 4.0 International (CC BY-NC-ND 4.0) licence. Under this licence, the contents are freely available online as PDF files (https://doi. org/10.14705/rpnet.2016.EUROCALL2016.9781908416445) for anybody to read, download, copy, and redistribute provided that the author(s), editorial team, and publisher are properly cited. Commercial use and derivative works are, however, not permitted.

\section{(9) $\Theta \Theta$}

Disclaimer: Research-publishing.net does not take any responsibility for the content of the pages written by the authors of this book. The authors have recognised that the work described was not published before, or that it is not under consideration for publication elsewhere. While the information in this book are believed to be true and accurate on the date of its going to press, neither the editorial team, nor the publisher can accept any legal responsibility for any errors or omissions that may be made. The publisher makes no warranty, expressed or implied, with respect to the material contained herein. While Research-publishing.net is committed to publishing works of integrity, the words are the authors' alone.

Trademark notice: product or corporate names may be trademarks or registered trademarks, and are used only for identification and explanation without intent to infringe.

Copyrighted material: every effort has been made by the editorial team to trace copyright holders and to obtain their permission for the use of copyrighted material in this book. In the event of errors or omissions, please notify the publisher of any corrections that will need to be incorporated in future editions of this book.

Typeset by Research-publishing.net

Cover design by (C) Easy Conferences, info@easyconferences.eu,www.easyconferences.eu

Cover layout by (c) Raphaël Savina (raphael@savina.net)

Photo "bridge" on cover by (C) Andriy Markov/Shutterstock

Photo "frog" on cover by (C) Fany Savina (fany.savina@gmail.com)

Fonts used are licensed under a SIL Open Font License

ISBN13: 978-1-908416-43-8 (Paperback - Print on demand, black and white)

Print on demand technology is a high-quality, innovative and ecological printing method; with which the book is never 'out of stock' or 'out of print'.

ISBN13: 978-1-908416-44-5 (Ebook, PDF, colour)

ISBN13: 978-1-908416-45-2 (Ebook, EPUB, colour)

Legal deposit, Ireland: The National Library of Ireland, The Library of Trinity College, The Library of the University of Limerick, The Library of Dublin City University, The Library of NUI Cork, The Library of NUI Maynooth, The Library of University College Dublin, The Library of NUI Galway.

Legal deposit, United Kingdom: The British Library.

British Library Cataloguing-in-Publication Data.

A cataloguing record for this book is available from the British Library.

Legal deposit, France: Bibliothèque Nationale de France - Dépôt légal: décembre 2016. 